Ann. Génét. Sél. anim., 1978, 10 (I), 6I-72

\title{
Contribution to the study of inheritance of laying performance and feed efficiency in the fowl under hot climatic conditions
}

\author{
A. OBEIDAH $(*)$, A. BORDAS, et P. MÉRAT \\ Laboratoire de Génétique factorielle, I.N.R.A., \\ Centre national de Recherches zootechniques, \\ $7835^{\circ}$ Jouy-en-Josas
}

\section{Summary}

Hens of four sire families and two genotypes for a plumage color gene (I $i$ and $i i$ ) were distributed equally at 7 months of age in two climatic rooms with individual cages, one "hot" $\left(27^{\circ} \mathrm{C}\right.$ at "night", $34^{\circ} \mathrm{C}$ on "day"), the other "temperate" (constant $20{ }^{\circ} \mathrm{C}$ ). In the same families segregation took place also, independently from the I locus, at the $P$ (pea comb) and $O$ (blue egg shell) loci. Production, egg traits, feed and water intake were recorded during three periods each of 28 days. Results are as follows:

I. As expected, a depression of production traits and feed intake is caused by the " hot" environment; water intake and body temperature are increased.

2. Significant sire family effects appear for most traits, without any detectable interaction associated with the other sources of variation.

3. Genotypes at the I locus show no difference for production traits or feed consumption and no interaction with treatment. On the other hand, pea-comb $(P p)$ hens as compared to their single comb sisters $(p p)$ have a significantly lower feed intake at high environmental temperature. A similar effect is observed for the $O o$ genotype ( $P$ and $O$ genes being linked).

4. Some correlations between weight of the whole egg and its components (yolk, albumen, shell) seem to differ for the $\mathrm{I} i$ and $i i$ genotype, and between environments.

\section{Introduction}

Laying stock developed by breeders in temperate climates has been improved for laying performance and egg quality traits in these climates, but in general not necessarily for production in hot climates.

On the other hand, the aim of poultry breeders is not only to maintain high production, but at the same time to minimize its cost, especially feed consumption

(*) Permanent address: Faculty of Agriculture, Cairo University, Egypt. 
of birds which represents about $60 \mathrm{p}$. Ioo of the total cost. However, feed efficiency is not only a biologically complex character, but also time-consuming to measure in a selection program. Few recent works investigated this character, and even fewer concern the effect of single genes (MERAT and BORDAS, I972, I974; MERAT, I975).

Performance in hot climatic condition, and particularly feed efficiency, can be considered as a trait correlated with the same trait measured in temperate conditions. MATHER and AHMAD (I97I) pointed out, on dwarf (dw) and normal hens, that heat had a depressing effect for both genotypes for feed and ME intake for immature and mature birds. It seems that no other single gene has been investigated with respect to its possible relation with heat tolerance of laying hens.

This work, therefore, had the purpose of detecting possible differences between the two genotypes $\mathrm{I} i$ and $i i$, and on the other hand between families, for laying performance and feed efficiency in a temperate condition $\left(20^{\circ} \mathrm{C}\right)$ and in a hot condition ( $34^{\circ} \mathrm{C}$ during day). In addition, on part of the data, possible effect of genotype at loci $\mathrm{P}$ (pea comb) and $\mathrm{O}$ (blue egg) was investigated. Moreover, correlations between performances within each environment were compared, concerning especially egg characteristics.

\section{Material and methods}

\section{I. - Experimental birds and conditions}

The birds used were issued from our experimental flock segregating for several marker genes. Breeding birds ( 4 sires, 15 dams) were chosen so as to realize the cross $\mathrm{I} i \times i i$ at locus I responsible for plumage color: about half the progeny were of the $\mathrm{I} i$ genotype (suppression of black pigment in the plumage), half were $i i$ (presence of black). The colored $i i$ birds had a black-red plumage owing to the presence of the $\mathrm{E}, e^{+}$or $e^{b}$ alleles for extension of black and of the $s$ allele for red pigmentation.

The I locus had been chosen because of a previously slight but significant difference between genotypes at this locus for feed efficiency of laying hens in a temperate environment (MERAT and BORDAS, I972).

On the other hand, some families were segregating (independently of the I gene) at the $\mathrm{P}$ and $\mathrm{O}$ loci. The types of crosses realized were respectively $\mathrm{P} p \times$ $p p$, giving half pea-comb $(\mathrm{P} p)$ and half single comb $(p p)$ progeny, and $\mathrm{O} o \times o o$, giving half blue-shell egg $(\mathrm{O} o)$ and half non-blue egg $(o o)$ daughters. The $\mathrm{P}$ and O genes (HuTT, I949) were linked in coupling in some families where they segregated both with their recessive allele; in other families only one of them segregated.

Birds were hatched in september 1976 . The female progeny of chosen breeding birds were raised on the floor till 16 weeks of age. Then they were placed in individual cages and distributed in equal numbers in two climatic rooms $(48$ cages in each), both with 14 hours light and ro hours darkness per 24 hours. From about 7 months of age (beginning in April 1977), one of these rooms (temperate room) was kept at constant $20^{\circ} \mathrm{C}$, the other at $27^{\circ} \mathrm{C}$ during the dark period, raising from onset of lighted period to $34^{\circ} \mathrm{C}$, this temperature being maintained till the onset of darkness. Percentage humidity was kept at 50 percent as far as 
possible. Each sire family, and as far as possible each single locus genotype within families, were distributed equally in the two environments. All birds received a $\mathrm{I} 6$ per cent protein and $2520 \mathrm{kcal} / \mathrm{Kg}$ M.E. ration given ad lib. in the form of pellets. The experimental period consisted of three consecutive periods each of 28 days (April to June I977).

\section{2. - Traits measured}

Several laying and egg traits were recorded during this time, as well as feed intake, water intake and morphological and physiological parameters. Egg number and percent cracked eggs are recorded for the total test period. Individual average body weight, variation in body weight, total egg mass and feed consumption were measured for each of the three 28 day periods. Daily water consumption was an average based on $I_{4}$ consecutive days in the last period. Mean egg weight corresponded to the last 28 day period, Albumen height and shell thickness were average values for eggs collected during two weeks in this same period (6 to $2 \mathrm{I}$ june). One egg per hen (in June) was broken to determine the weight of its components, and another egg was used to measure the weight of shell membranes after washing and drying at room temperature during 48 hours. The temperatures were read to the nearest $0 .{ }^{\circ} \mathrm{C}$ with a thermocouple connected with two different

TABLE I

Traits measured: Symbols used and their descriptions

Caractères mesurés: symboles utilisés et description

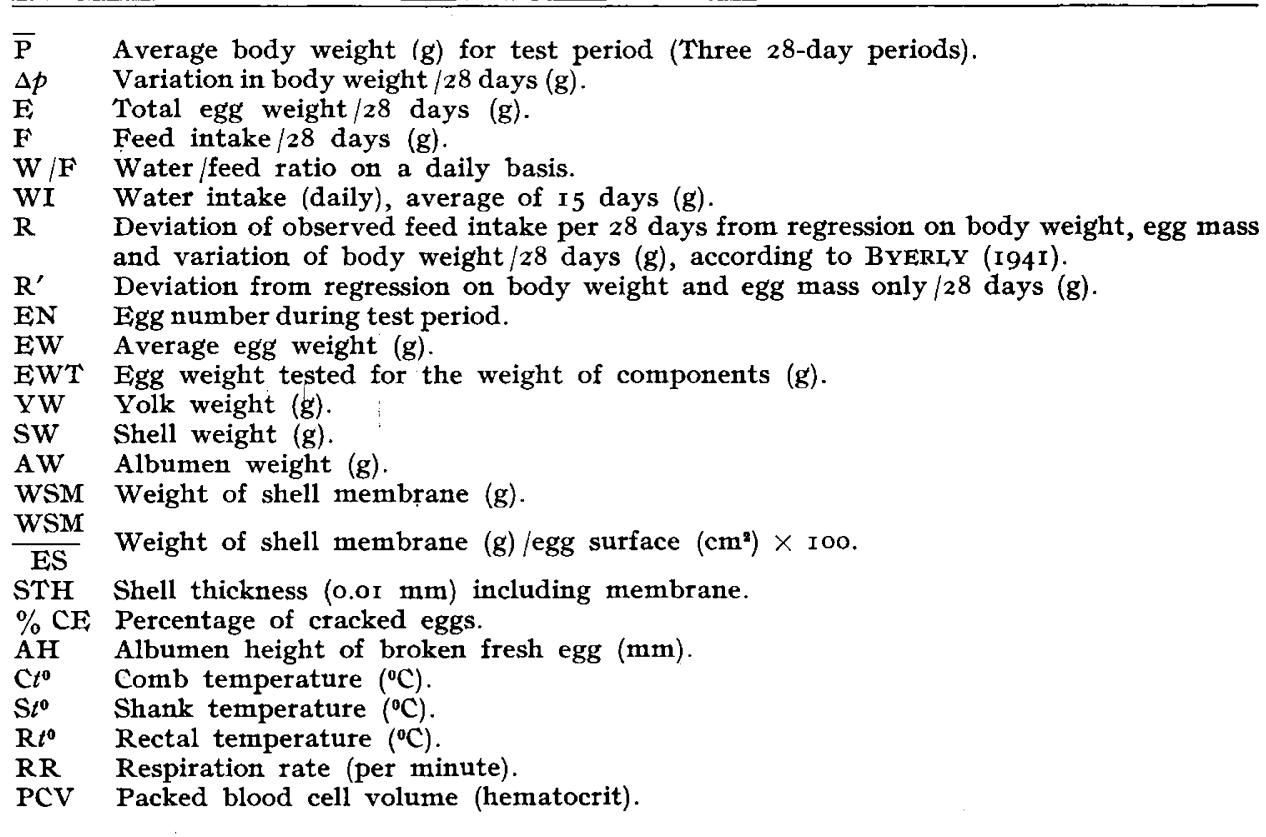



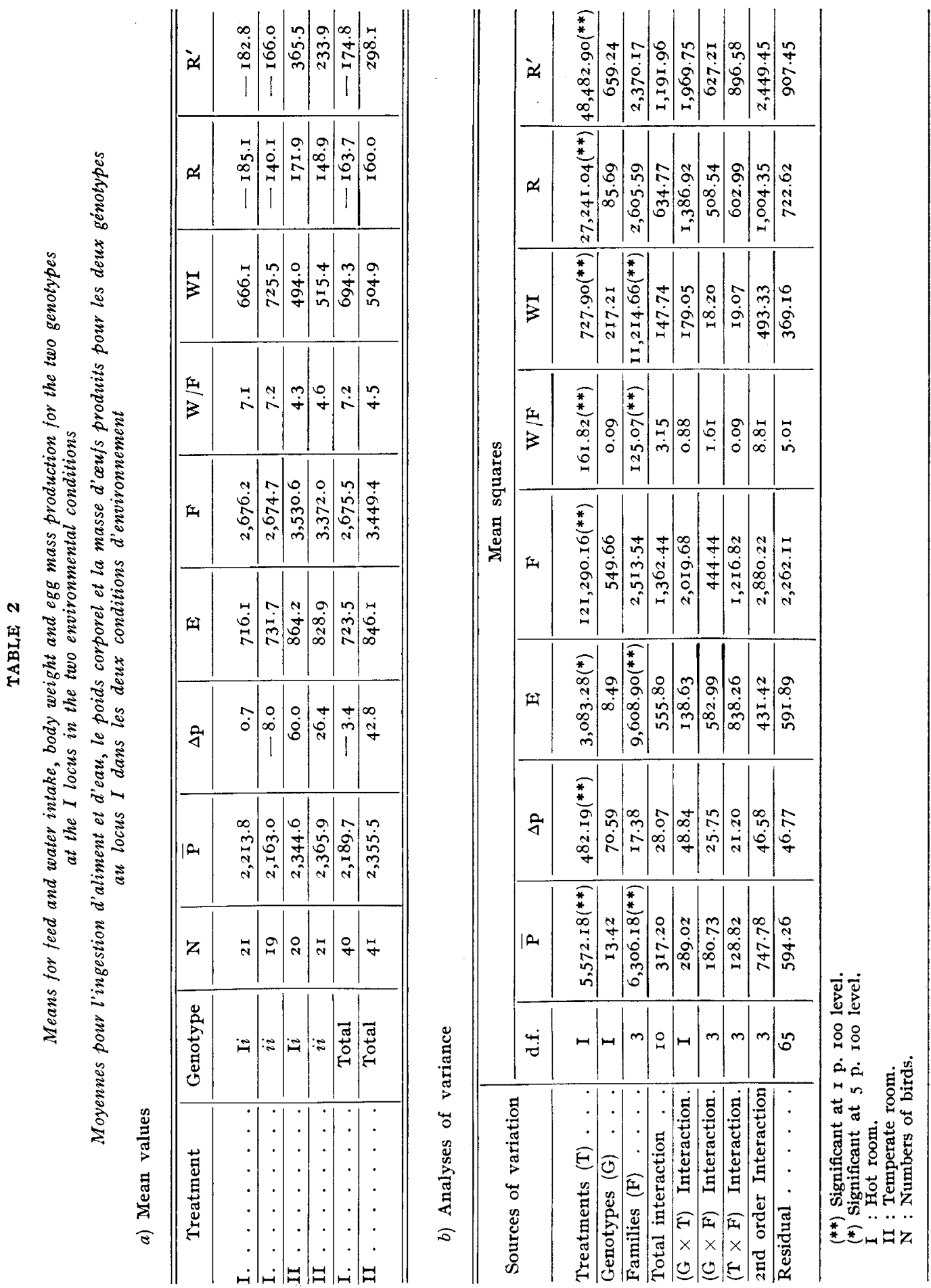
probes, one for rectal and another for surface temperatures. Respiration rate per minute was estimated only on birds kept in the " hot" cell. Temperatures and respiration rate were measured, for each individual, once in the third week of each 28 day period, around 2 p.m. Hematocrit was measured once at the end of the experiment.

For each individual, only the average value is considered for traits with repeated measurement and only birds having all measurements recorded are considered.

Table I summarizes the definition of observed traits and abbreviated symbols designating them in the following tables.

\section{3. - Statistical analysis}

For each trait, analysis of variance was done including all birds, with environment, sire family and genotype at the I locus ( $\mathrm{i} i$ vs $i i$ ) as controlled sources of variation.

For the comparison between $\mathrm{P} p$ and $p p$ or between $\mathrm{O} o$ and $o o$ genotypes, it is restricted to pairs of full sisters, on which a $t$ test is made for the different traits.

Finally, phenotypic correlation coefficients are estimated for some traits within environments and also within genotypes at the $\mathrm{I}$ and $\mathrm{O}$ loci.

\section{Results}

Tables 2, 3 and 4 show the means and analyses of variance for the traits studied with respect to the effect of treatments, genotypes at the I locus and sire families. Tables 5 and 6 give respectively the means and $t$ tests for comparison of $\mathrm{O} o$ vs $o o$ and $\mathrm{P} p$ vs $p p$ genotype for all traits.

For most of the phenotypic correlations between traits, it is preferred, because of the limited numbers available, to pool them for several experiments in a separate work. However, correlations including egg weight and weight of egg components, which are specific to the present experiment, are considered here. Table 7 contains these correlations within the $I i$ and $i i$ genotype within each treatment, then compared for the two environments with genotypes pooled on a within environment basis, and finally for the two genotypes grouping environments on a within genotype basis.

\section{Discussion}

\section{I. - Treatment and family differences}

As in shown in tables 2 to 4 , the higher environmental temperature, as compared to constant $20^{\circ} \mathrm{C}$, has a significant to highly significant depressing effect on feed intake, egg mass produced, body weight and weight gain, average weight of the egg and its components, shell thickness, and hematocrit value. Egg number is depressed and percent cracked eggs is increased but not significantly. Water intake is significantly higher, and the same for water/feed ratio and for surface 


\begin{tabular}{|c|c|c|c|c|c|c|}
\hline 要 & $\stackrel{\leftrightarrow}{r}$ & î & 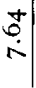 & 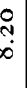 & & 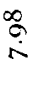 \\
\hline $\begin{array}{l}\text { II } \\
0^{\circ}\end{array}$ & $\stackrel{m}{\dot{n}}$ & $\tilde{\omega}$ & $\tilde{0}$ & 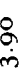 & & $\mid \begin{array}{l}n \\
\infty \\
\dot{\gamma}\end{array}$ \\
\hline 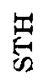 & $\begin{array}{l}\stackrel{+}{3} \\
\stackrel{m}{m}\end{array}$ & î & $\begin{array}{l}n \\
\stackrel{0}{0} \\
\dot{m} \\
m\end{array}$ & $\begin{array}{l}m \\
\tilde{m} \\
m\end{array}$ & & $\begin{array}{l}\AA \\
0 \\
0 \\
0\end{array}$ \\
\hline 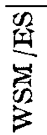 & $\begin{array}{l}\vec{z} \\
\vec{N} \\
0\end{array}$ & $\begin{array}{l}\infty \\
\infty \\
\infty \\
0 \\
0\end{array}$ & $\begin{array}{l}0 \\
\stackrel{4}{*} \\
\vdots \\
0\end{array}$ & 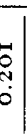 & 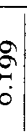 & 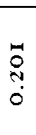 \\
\hline $\begin{array}{l}\vec{k} \\
n \\
\xi\end{array}$ & $\begin{array}{c}\stackrel{P}{-} \\
\stackrel{0}{0}\end{array}$ & 量 & $\begin{array}{c}m \\
\stackrel{m}{0} \\
0\end{array}$ & $\begin{array}{c}2 \\
0 \\
0\end{array}$ & & $\stackrel{\widehat{m}}{\stackrel{0}{0}}$ \\
\hline 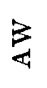 & $\begin{array}{l}\stackrel{9}{0} \\
\dot{0} \\
\dot{m}\end{array}$ & $\begin{array}{l}\hat{\sigma} \\
\dot{\rho} \\
\dot{m}\end{array}$ & $\begin{array}{l}n \\
\tilde{n} \\
m \\
m\end{array}$ & $\stackrel{\infty}{m}$ & $\begin{array}{l}\dot{n} \\
\dot{m} \\
\dot{m}\end{array}$ & $\stackrel{\hat{i}}{\hat{j}}$ \\
\hline 范 & $\begin{array}{l}\mathscr{6} \\
\dot{q}\end{array}$ & $\begin{array}{c}\hat{*} \\
\infty \\
\dot{\sigma}\end{array}$ & $\begin{array}{l}\tilde{0} \\
\dot{n}\end{array}$ & $\begin{array}{l}\delta \\
\delta \\
\dot{\sigma} \\
\end{array}$ & $\hat{N}$ & $\stackrel{\text { gे }}{\dot{q}}$ \\
\hline 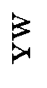 & $\begin{array}{c}\infty \\
\infty \\
\infty \\
\dot{m} \\
\end{array}$ & $\hat{0}$ & $\begin{array}{l}\hat{\imath} \\
\dot{0} \\
-1\end{array}$ & $\stackrel{m}{0}$ & & $\begin{array}{l}\stackrel{+}{n} \\
\stackrel{0}{0}\end{array}$ \\
\hline 皇 & $\begin{array}{l}8 \\
\dot{\sigma} \\
\sigma\end{array}$ & 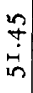 & ộ & $?$ & & $\begin{array}{l}0 \\
\infty \\
\\
\end{array}$ \\
\hline 莏 & $\begin{array}{l}\infty \\
m \\
\sigma \\
\sigma \\
+\end{array}$ & $\begin{array}{l}\infty \\
\infty \\
\alpha \\
\alpha\end{array}$ & $\begin{array}{l}\hat{y} \\
\dot{n} \\
\end{array}$ & 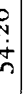 & & $\begin{array}{l}\text { ô } \\
\text { +े } \\
\text { in }\end{array}$ \\
\hline 目 & $\begin{array}{l}0 \\
\dot{m}\end{array}$ & $\stackrel{\mathscr{m}}{\dot{\sigma}}$ & $\begin{array}{c}0 \\
\infty \\
\dot{0} \\
\forall\end{array}$ & dُ & & $\begin{array}{l}a \\
\dot{6}\end{array}$ \\
\hline Z & $\tilde{\text { t }}$ & 20 & $\stackrel{i}{N}$ & & $q$ & $\stackrel{\circ}{q}$ \\
\hline 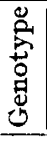 & $\tilde{\sim}$ & $: ₹$ & $\tilde{\sim}$ & & & 氶 \\
\hline 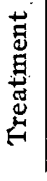 & & & & & & \\
\hline
\end{tabular}

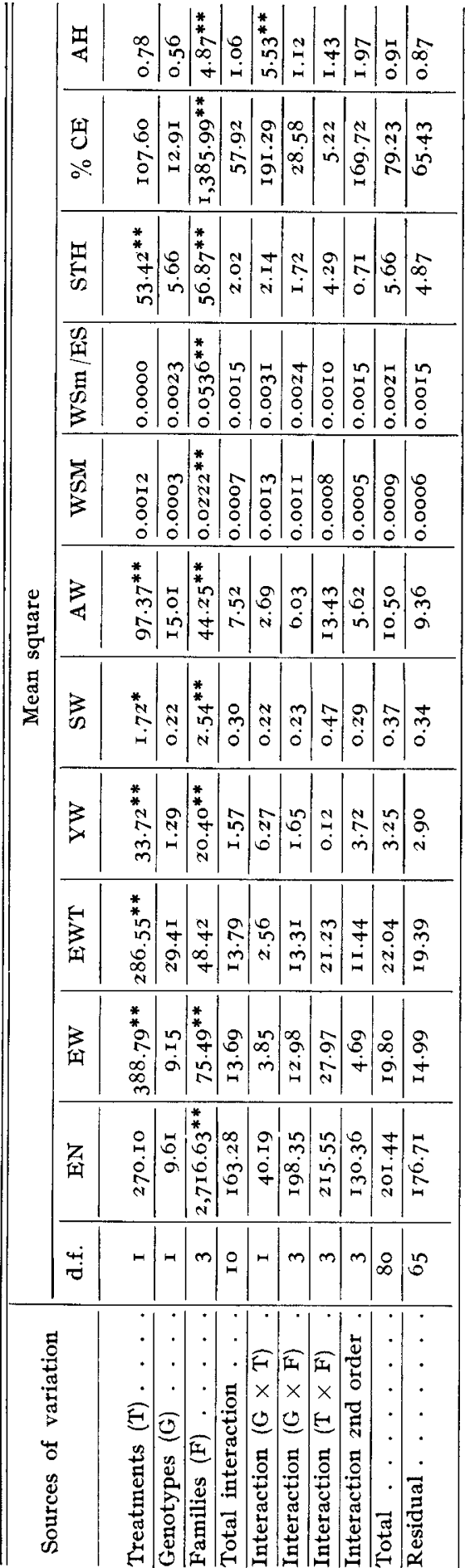


TABLE 4

Means and analyses of variance for body temperatures, Packed cell volume and respiration rate.

Moyennes et analyses de variance pour les températures corporelles, l'hématocrite et le rythme respiratoire.

a) Means

\begin{tabular}{|c|c|c|c|c|c|c|c|}
\hline Treatment & Genotype & $\mathbf{N}$ & $\mathrm{C} t^{\circ}$ & $\mathrm{S} t^{0}$ & $\mathrm{R} t^{0}$ & $\mathrm{RR}\left({ }^{*}\right)$ & $\mathrm{PCV}$ \\
\hline I....... & $\mathrm{I} i$ & $2 \mathrm{I}$ & 38.87 & $3^{8.84}$ & $4 \mathrm{I} .2 \mathrm{I}$ & I 20.8 & 27.62 \\
\hline $\mathrm{I} \ldots \ldots$ & $i i$ & 19 & 38.68 & 38.66 & $4^{\mathrm{I} .08}$ & I 21.9 & 28.50 \\
\hline $\mathrm{II} \ldots . .$. & $\mathrm{I} i$ & 20 & 34.30 & 33.90 & 40.00 & & $29.5^{\circ}$ \\
\hline II . . . . . & $i i$ & $2 \mathrm{I}$ & $33 \cdot 76$ & $33.4^{\circ}$ & $4^{0.04}$ & & 30.29 \\
\hline I........ & Total & 40 & 38.88 & $3^{8.76}$ & $4 \mathrm{I} . \mathrm{I} 5$ & $\mathrm{I} z \mathrm{I} \cdot 3$ & 28.05 \\
\hline II ...... & Total & $4 \mathrm{I}$ & 34.02 & 33.64 & 40.03 & & 29.88 \\
\hline
\end{tabular}

(*) Respiration rate was measured only on birds in the hot room.

I : Hot room.

II : Temperate room.

b) Analyses of variance

\begin{tabular}{|c|c|c|c|c|c|c|c|}
\hline \multirow{2}{*}{$\begin{array}{c}\text { Sources } \\
\text { of variation }\end{array}$} & \multicolumn{5}{|c|}{ Mean squares } & \multirow{2}{*}{ d. f. } & M. S. \\
\hline & d. f. & $\mathrm{C} t^{0}$ & $\mathrm{~S} t^{0}$ & $\mathrm{R} t^{0}$ & $\mathrm{PCV}$ & & $\mathrm{RR}$ (I) \\
\hline Treatments $(T)$ & $\mathbf{I}$ & $465.94(* *)$ & $529.02(* *)$ & $25.35(* *)$ & $65.87\left(^{* *}\right)$ & & \\
\hline Genotypes $(\mathrm{G})$. . & $\mathbf{I}$ & $5.39(* *)$ & $5.59(* *)$ & 0.22 & I 6.87 & $\mathbf{I}$ & 24.62 \\
\hline Families (F). . . & 3 & I $0.66\left(^{* *}\right)$ & $6.91 \quad(* *)$ & $0.49(* *)$ & 0.14 & 3 & $557.3^{\circ}(*)$ \\
\hline Total interaction & Io & 0.32 & 0.28 & 0.07 & 5.23 & 3 & 323.67 \\
\hline Residual . . . . & 65 & $0.7 \mathrm{I}$ & 0.92 & 0.07 & $9.4 \mathrm{I}$ & $3 z$ & 166.32 \\
\hline
\end{tabular}

(**) Significant at $\mathrm{r}$ p. roo level.

(*) Significant at $5 \mathrm{p}$. roo level.

I) The analysis of variance for $R R$ is between genotypes and families (only one treatment).

and internal body temperatures. These results are in concordance with the generally observed effects of high ambient temperature in the literature (e.g. review by SMITH and Oliver, I97I). On the other hand, weight of shell membranes and albumen height are not significantly affected by treatment.

Significant sire family differences are apparent for most traits, but no interaction including families is significant for any trait, suggesting that breeding for these traits in one environment may be satisfactory for improvement in the other. 


\section{TABLE 5}

Means and " $t$ " tests for all traits with respect to $(O o$, oo) genotypes Moyennes et tests " $t$ " pour tous les caractères relativement aux génotypes Oo et oo

a) Temperate environment $\left(^{*}\right)$

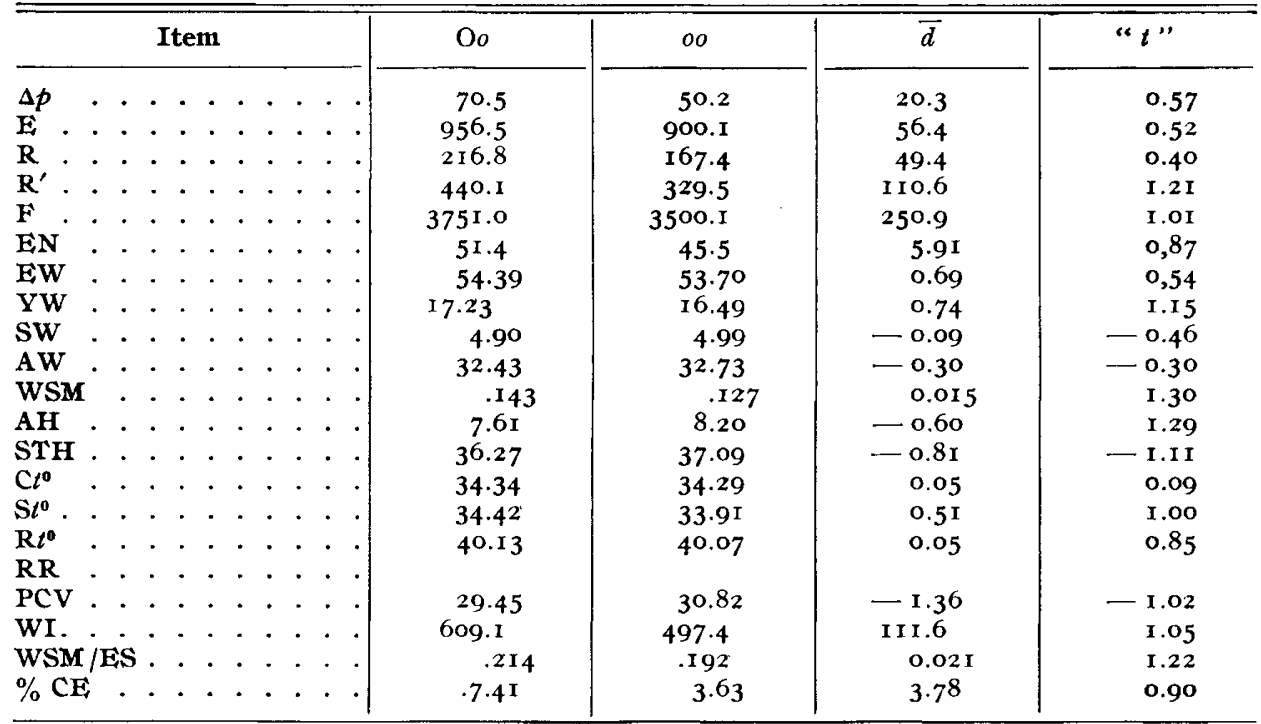

(*) II pairs.

b) Hot environment (*)

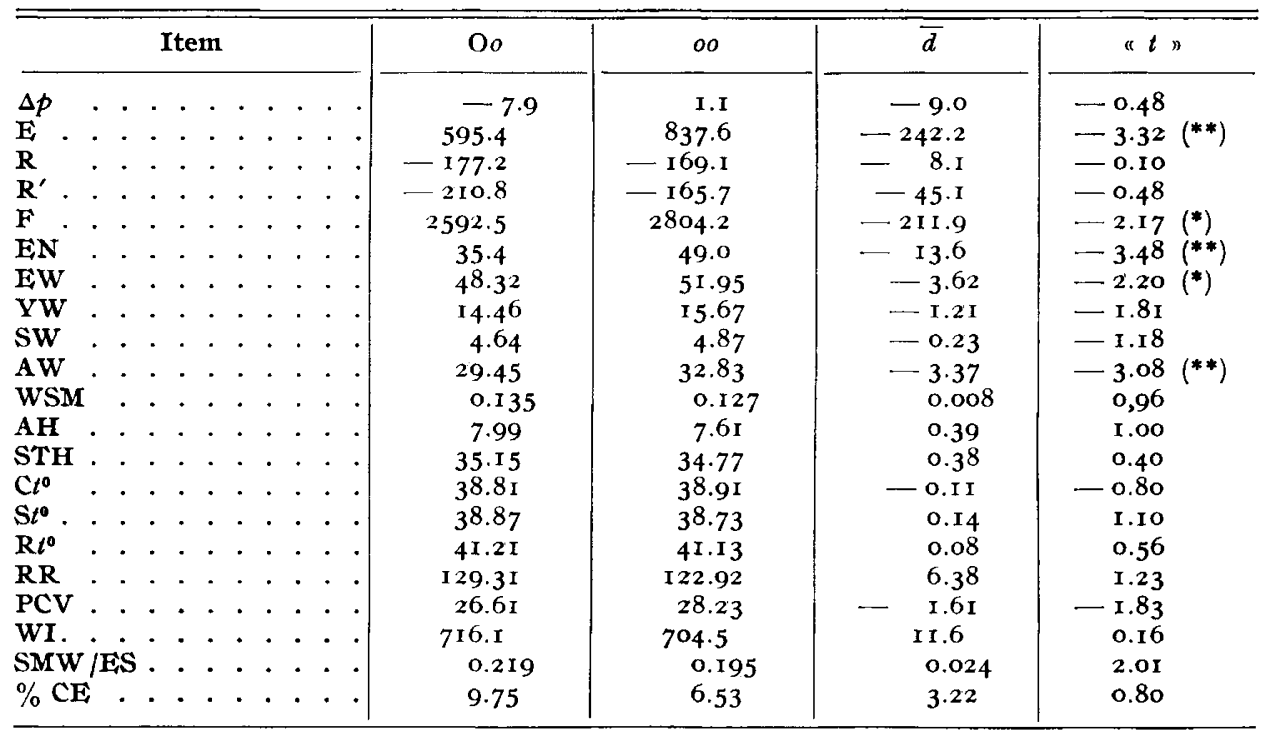

(*) 13 pairs. 


\section{TABLE 6}

Means and $t$ tests for all traits with respect to $P p$ and $p p$ genotypes Moyennes et tests $t$ pour: tous les caractères relativement aux génotypes $P p$ et $p p$

a) Temperate environment $\left({ }^{*}\right)$

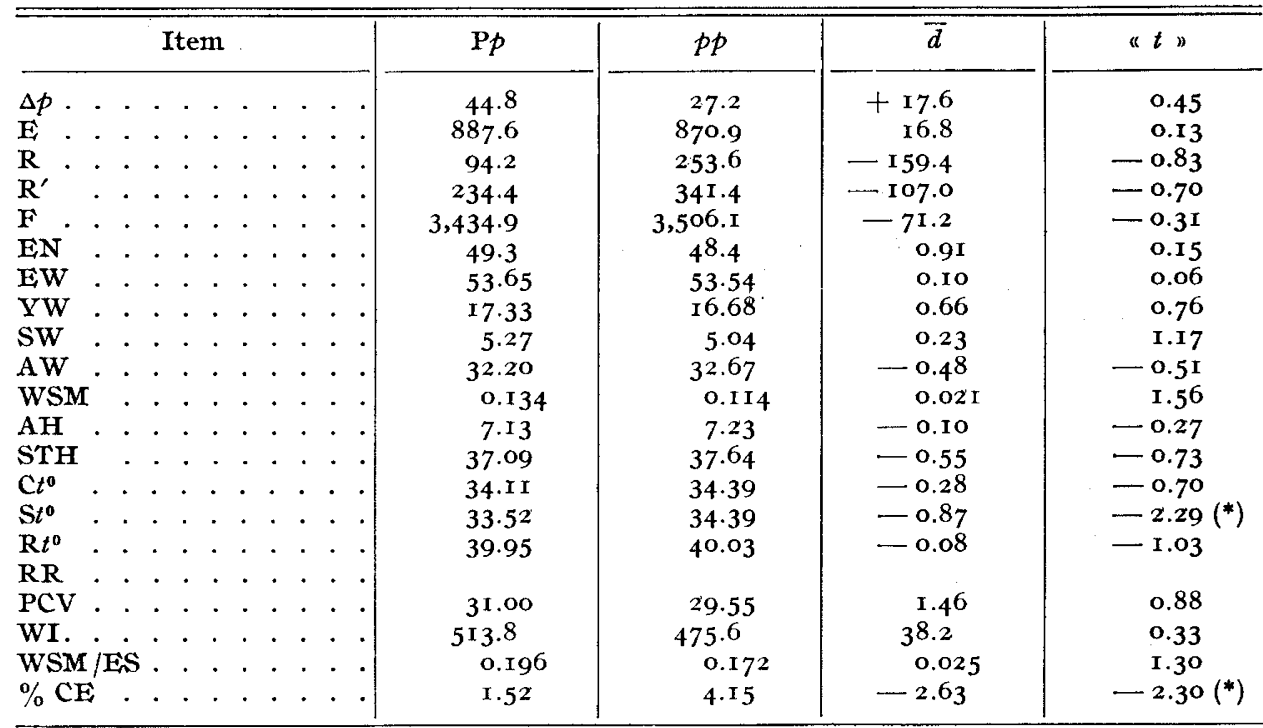

(*) II pairs.

b) Hot environment (*)

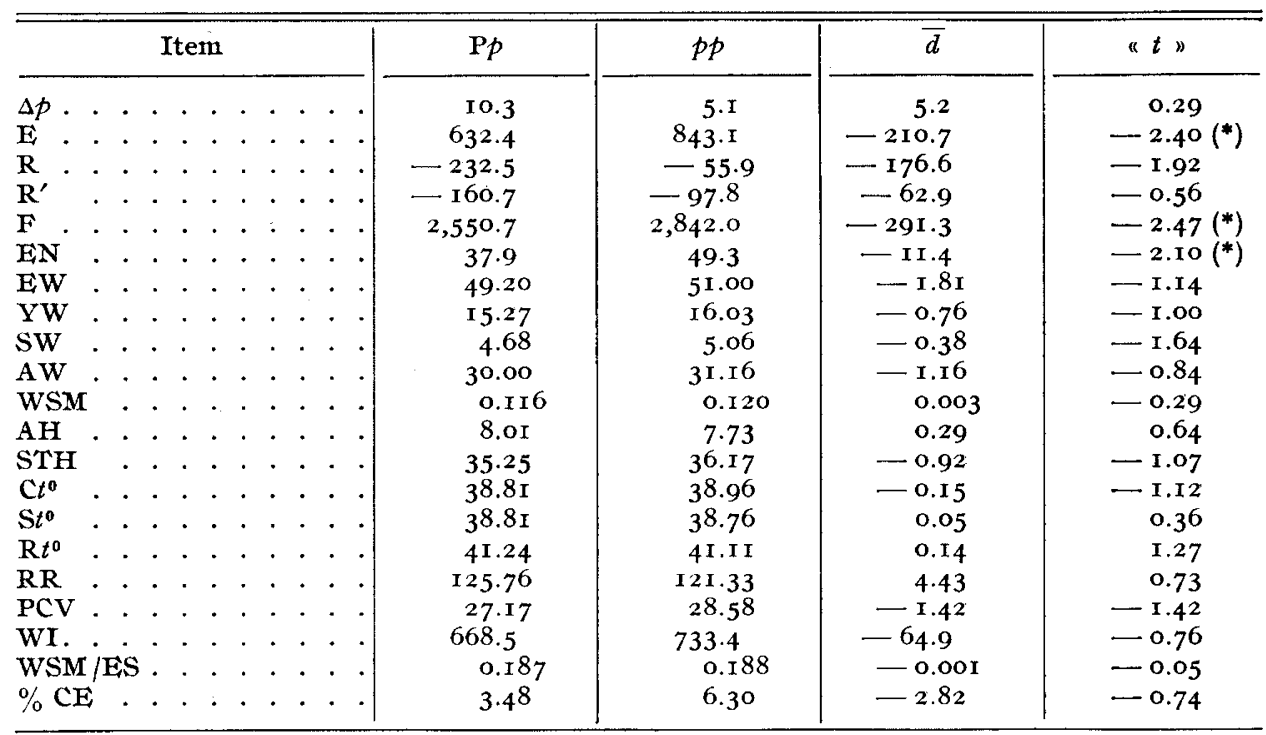

(*) 12 pairs. 
Correlations between egg weight and components wei६ Corrélations entre le poids de l'œut et de ses composantes

\begin{tabular}{|c|c|c|c|c|c|c|c|c|}
\hline & \multicolumn{4}{|c|}{$\left(\mathrm{I} i: n=20 \quad \stackrel{\text { Normal }}{\left(20^{\circ} \mathrm{C}\right)}\left({ }^{1}\right)\right.$} & \multicolumn{4}{|c|}{ 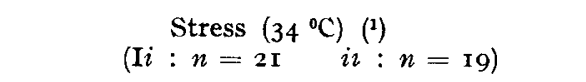 } \\
\hline & EW & YW & Sw & AW & EW & YW & sw & AW \\
\hline $\mathrm{EW}$ & 一 & 0.210 & 0.246 & $0.555\left(^{*}\right)$ & - & 0.6 I I $\quad(* *)$ & $0.77^{(* *)}$ & $0.717\left(^{*}\right.$ \\
\hline YW & $0.64 \mathrm{I} \quad(* *)$ & - & $0.583(* *)$ & 0.158 & $0.77^{\circ}(* *)$ & $\ldots$ & $0.526\left(^{*}\right)$ & 0.215 \\
\hline SW. & $0.63 \mathrm{I}(* *)$ & 0.234 & - & $0.27 \mathrm{I}$ & $0.510\left(^{*}\right)$ & 0.209 & - & $0.5971^{*}$ \\
\hline$\overline{A W}$ & $0.9 \operatorname{Ir}(* *)$ & 0.306 & $0.508\left(^{*}\right)$ & 一 & $0.960(* *)$ & $0.579\left(^{* *}\right)$ & $0.46 \mathrm{I} \quad\left(^{*}\right)$ & - \\
\hline
\end{tabular}

(I) For the normal and stress condition $\mathrm{Ii}$ is below the diagonal and ii is above.

(2) Lower for $\left(34^{\circ} \mathrm{C}\right)$ and upper for $\left(20^{\circ} \mathrm{C}\right)$.

(3) Lower for Ii, upper for ii.

(*) Correlation significant at 5 p. roo level.

(**) Correlation significant at $x$ p. roo level.

\section{2. - Differences associated with single genes}

Tables 2, 3 and 4 show that no effect is associated with genotype at the I locus, except a significant but slight difference for comb and shank temperature. No interaction appears between genotypes at this locus and treatment or sire family, with an exception for the trait " albumen height", with no obvious interpretation.

In particular, the slight but significant association found previously between plumage color ( $\mathrm{I} i$ vs $i$ ) and " residual" feed consumption is not found in the present study.

On the other hand, in spite of the limited numbers available, tables 5 and 6 show respectively several significant differences associated to the $O$ and $P$ loci in the " hot" environment: For both Oo and Pp genotypes as compared to their recessive counterpart, total feed intake (F) and egg number (EN) are lower: the same holds for egg and albumen weight for Oo hens.

As $\mathrm{O}$ and $\mathrm{P}$ are linked in coupling in part of our data, this effect might be attributed to either of the corresponding loci. It is interesting to note that pooling with other pairs of sisters, one with peacomb and blue egg shells ( $\mathrm{P} p \mathrm{O} o$ ), the other with single comb and shells without blue pigment ( $p p o o)$, submitted to similar " hot" conditions during the same 3 month period of the year in 1974 and 1976 (unpublished data), a significantly lower feed intake appears for $\mathrm{P} p \mathrm{O} o$ birds: on $4 \mathrm{I}$ pairs of individuals on the whole, averages of the two genotypes for feed intake per 28 days are respectively $2344 \mathrm{~g}$ and $2576 \mathrm{~g}(\mathrm{P} \simeq 0.02)$. For egg mass the corresponding figures are $532 \mathrm{~g}$ and $622 \mathrm{~g}(\mathrm{P} \simeq 0$. Io). 
the two genotypes in normal and heat stress conditions

deux génotypes en condition normale ou de stress thermique

\begin{tabular}{|c|c|c|c|c|c|c|c|}
\hline \multicolumn{4}{|c|}{$\begin{array}{l}\text { Grouping the two genotypes } \\
\text { within environments }\left(^{(2)}\right.\end{array}$} & \multicolumn{4}{|c|}{$\begin{array}{l}\text { Grouping the two environments } \\
\text { within genotypes }\left({ }^{(3)}\right.\end{array}$} \\
\hline EW & YW & sw & AW & EW & YW & sw & AW \\
\hline - & $0.446(* *)$ & $0.455^{(* *)}$ & $0.662(* *)$ & - & $0.420(* *)$ & $0.553\left(^{* *}\right)$ & $0.63^{8(* *)}$ \\
\hline $0.722(* *)$ & $\cdots$ & $0.427(* *)$ & $0.23^{\circ}$ & $0.713(* *)$ & - & $0.557^{(* *)}$ & 0.185 \\
\hline $0.619\left(^{* *}\right)$ & $0.37 x\left(^{*}\right)$ & 一 & $0.393\left(^{*}\right)$ & $0.57^{2}(* *)$ & $0.22 \mathrm{I}$ & 一 & $0.4399^{(* *)}$ \\
\hline $0.937\left(^{(* *}\right)$ & $\left.0.4544^{* *}\right)$ & $0.519\left({ }^{* *}\right)$ & $\cdots$ & $\left.0.94 I^{(* *}\right)$ & $0.457\left(^{* *}\right)$ & $0.4^{8} 4^{(* *)}$ & 一 \\
\hline
\end{tabular}

It may be suggested that the small comb and wattles associated with the $\mathrm{P} p$ genotype are responsible for depressed feed intake and egg production by reducing heat dissipation rate in the head region. One way of partially checking this hypothesis will be comparing genotypes at the $\mathrm{P}$ locus independently of the $\mathrm{O}$ gene.

\section{3. - Correlations between egg characters}

From table 7 it may be seen that on the whole, for the $\mathrm{I} i$ genotype, the correlation between egg weight (EW) and albumen weight (AW) is significantly higher $(\mathrm{P}<0.00 \mathrm{I})$ than for the $i i$ genotype. One can note also that the $\mathrm{YW}-\mathrm{AW}$ correlation is higher for the former genotype, though not significantly so. This suggested difference in correlations between egg weight and weight of some egg components may have some analogy to that already mentioned by OBEIDAH et al. (1977).

On the other hand, the EW-AW correlation is somewhat higher in the " hot " environment than in the "temperate" condition. This may correspond to the lower egg weight, on the average, in the former environment.

It may be mentioned in addition that a similar comparison of correlations between weights of the whole egg and its components in the $\mathrm{O} o$ and oo genotypes does not show any significant difference associated with these genotypes. 


\title{
Remerciements
}

Nous remercions le Dr P. E. Bernier (Oregon State University, CorvalLis, U.S.A.) et le Dr A. MostageER (Cairo University, Giza, Égypte) pour leurs utiles remarques et suggestions concernant ce manuscrit.

\author{
Résumé \\ Contribution à l'étude de l'hérédité de la ponte \\ et de l'efficacité alimentaire de la poule en condition climatique chaude.
}

Des poules issues de quatre familles de pères et de deux génotypes de couleur du plumage (I $i$ et $i i$ ) ont été réparties également à 7 mois d'âge dans deux chambres conditionnées avec cages individuelles, $1^{\prime}$ une chaude $\left(27^{\circ} \mathrm{C}\right.$ la " nuit ", $34^{\circ} \mathrm{C}$ le " jour "), $1^{\prime}$ autre tempérée $\left(20^{\circ} \mathrm{C}\right.$ en permanence). Dans ces mêmes familles existait aussi une ségrégation, indépendamment du locus $\mathrm{I}$, aux loci $\mathrm{P}$ (crête en pois) et $\mathrm{O}$ (œufs à coquille bleue). La ponte, des caractères des œufs, la consommation d'aliment et d'eau étaient enregistrées pendant trois périodes de 28 jours. Les résultats sont les suivants :

I. Comme prévisible, une diminution de la masse d'œufs produite et de la consommation d'aliment est causée par l'environnement chaud; la consommation d'eau et la température corporelle sont augmentées.

2. Des effets familiaux significatifs apparaissent pour la plupart des caractères, sans interaction décelable avec les autres facteurs contrôlés.

3. Les génotypes au locus I ne montrent aucune différence pour les caractères de production ou la consommation alimentaire et pas d'interaction avec le traitement. D'autre part, les poules à crête en pois $(\mathrm{P} p)$ comparées à leurs sœurs à crête simple $(p p)$ ont une consommation alimentaire significativement inférieure à température ambiante élevée. Un effet semblable est observée pour le génotype $\mathrm{O} o$ (les gènes $\mathrm{P}$ et $\mathrm{O}$ étant liés).

4. Certaines corrélations entre les poids de l'œuf entier et de ses composants (jaune, albumen, coquille) paraissent différer pour les génotypes $\mathrm{I} i$ et $i i$, et entre environnements.

\section{Références}

BYERLY T. C., I94I. Feeds and other costs of producing market eggs. Univ. of Maryland Agric. Exp. Sta. Bul., no Ar.

HUTr F. B., I949. Genetics of the fowl. Mc Graw Hill, New-York.

MATHER F. B., AHMAD M. M., I97I. Initial physiological responses of dwarf and normal laying hens to an abrupt increase in environmental temperature. Poult. Sci., 50, 1604 (abstr.).

MERAT P., I975. Indirect selection in poultry breeding with special reference to single genes. Ann. Genet. Sel. anim., 7, 449-460.

MERAT P., BORDAS A., I972. Consommation alimentaire de pondeuses blanches (I $i$ ) et colorées (ii). Ann. Génét. Sél. anim., 4, 375-384.

MERAT P., Bordas A., 1974. Consommation alimentaire d'animaux à plumage réduit (gène $\mathrm{Na}$ ) ou normal en présence ou en l'absence du gène de nanisme dw. Ann. Génét. Sél. anim., 6, 1 7-28.

Obeidah A., Merat P., DURand L., I977. Polymorphism of egg white proteins, egg weight and components weights in the Fayoumi hen. Ann. Génét. Sél. anim., 9, 27-32.

SMIrH A. J., OLIVIER J., I97I. Some physiological effects of high environmental temperatures on the laying hen. Poult. Sci., 50, 912-925. 